tirely concur with Mr. Bull. From the details given in the "Defence;" from the correspondence between the author of the memoir and the commitfee; from the form of the objections and remarks, it may be seen that the committee were more occupied with their own opinions on the subject, than in examining the work submitted to them. We do not doubt their impartiality; we rejoice to perceive that they have been always animated with the most praiseworthy zeal for science; for those who cultivate it, and for the arts which it enlightens and directs; but in the history of academical prizes, this decision, so contrary to the opinion of the scientific world, ought not to be omitted.

Mr. Bull has deserved well of the republic of letters, in bringing this discussion before the public: we may at a future day draw from it some useful warnings; and learned societies, if they continue to distribute prixes, will take care that their judgment shall not be condemned by the irrefragable authority of the public.

\title{
Franktix Institute.
}

The twenty-first quarterly meeting of the Institute was held at their Hall, on the 16th of April, 1829.

Mr. Abramam Minler was called to the chair.

The minutes of the last quarterly meeting were read and adopted.

The quarterly report of the board of managers was read and accepted. was

In pursuance of the recommendation of the board of managers, it

Resolved, That monthly meetings of the Institute be held for the purpose of discussing mechanical and scientific questions.

Resolved, That the meetings be held on the fourth Thursday evening in every month.

Extract from the minutes.

\section{A. S. Ronerts, Recording Secretary.}

\section{A. Miliek, Chairman.}

The Twenty-first Quarterly Report of the Managers of the Frankinn Institute of the State of Pennsyluania, for the Promotion of the Mechanic Arts.

In conformity with the laws of the institution, the board of managers of the Franklin Institute present a report of their proceedings during the last quarter.

Since their last report, the drawing school of the Institute has been closed for the season. The board have great satisfaction in stating that it has been conducted in an able and efficient manner, has been much more extensively patronized than in some former years, and productive of corresponding advantage. 
The mathematical school has also been closed, and to this degurt. ment, likewise, an increased attention has been directed by mechan. ics, and a high degree of interest excited, from which the bourd anticipate the most beneficial effects.

$\Lambda$ semi-annual examination of the high school was held on the $19 \mathrm{sh}$, 13th and 14th of March last, under the superintendence of the coms. mittee of instruction. The order and attention of the propits, their acquirements in the ancient and modern languages, in mathematics, in geography, and grammar, and in the subjects of their studies generally, were such as reflect great credit on themselves and on their instructers.

The regular courses of lectures bave terminated for the seasn. They have been as well attended as in former years, and have cota. tributed largely to increase the mass of scientific infornation al. ready diffused through our community. Volunteer lectures have also been delivered nearly every Saturtay evening during the past season, comprising a series of lectures on the important and interest . ing science of geology by Peter $\boldsymbol{\Lambda}$. Browne, Fay., and a number of lectures on optics and miscellaneous subjects equally interesting by Mr. Lcib. The institution is greatly indebted to both these gente. men.

The library has received several alditions since the date of the last quarterly report, by purchase, donation and exchange, comprising some valuable works. The libtary is kept in the managers' room, which is warmed and lighted every evening, and is open to the members of the Institute. Several of the daily jouraals are also received.

In the same apartment commodious cases have been placed, for the reception of minerals, which, although not at present scientifically arranged, may be inspected with advantage. Many specimeas are yet wanting, which, by a little attention to the subject on the part of the members of the Institute, might be readily supplied, without expense to the Institute, or to the individual members.

From the report of the committee on publications, it appears, that the Journal of the Franklin Institute has been so conducted, ss not only to sustain its reputation, but to increase its usefulness, and, ats the board believe, under happier auspices. Arrangements tave been made for obtaining a very considerable portion of onfinal nuter for its pages. These arrange ments embrace a circle of yaried and weful talent, from the resources of which the board have great confilence that the subscribers will derive misch valanble intormation.

In accordunce with a resolution of the board, adopted at thein meeting on the 12 h of March, the following plan for toblding month Iy meetiags of the members of the Institute is proposed for your con sideration and encouragement. Much gond is expected to result from the adoption of the measure. The persoul acquantatuce of the nembers with each other: the familiar interchastuge of ithas on philosophical and mechanical subjects, and such as pertain to the arts generally; the free discussion of unsettled pointe, and the concentra. tion of the wandering and fugitive rays of knewledge nh any am! every subject embraced amongt the thind of ott matution. Many 
isolated facts are known to individuals, which are entirely useless to them, but which, when communicated, add to the stock of know. ledge. No one, it is believed, can attend these meetings without deriving from them some advantage. The minds of few men, indeed, are so sterile as to be incapable of making any contribution to the treasury of useful ideas, and few will believe their intellectual weal th too great to be susceptible of increase.

The plan proposed by the committee appointed by the board for that purpose, provides for the fitting up of the lecture room; the arranging thercin the architectural models; the erection of cases, and the placing in them of the apparatus belonging to the Institute; and the convenient fixing of tables.

The orele of business at these meetings to be as follows:-

1st. 'The realing the minutes of the last meeting.

and. Bonations to the cabinet of models, apparatus, and minerals, received.

3d. Donatious to the ibrary received.

4th. Reports of officers and committees.

5th. Unfinished business.

6 th. Written communications received and discussed.

7 th. Verbal communications received and discussed.

Stil. Motions.

9ih. Selection of questions for discussion at the next meeting.

At a mecting of the board of managers, on the 12th of March, it was unanimously resolved to adopt measures for instituting a series of experiments, to ascertain " the value of water as a moving power, and the relative effects produced by it on (water) wheels of different constructions." This object is one of the greatest importance which has cone before the Institute.

It is true, that we are not entirely destitute of information on the subject. The talents and experience of many eminent men have been directed to this end, but the progress of desultory or accidental expericnce is tardy and uncertain; and the expense of direct and continued experiments, on a scale sufficiently large to produce the most certain results, is tno great to come frequently within the range of individual enterprise; but even these have not been entirely wanting. Men whose names are neither unknown or unrenowned in the annals of science, have instituted experiments on the same subject; but however much they have illustrated it by their talents and sagacity, much remains to be effected. To do this, is the object of your board. 'They do not pretend to arrogate to themselves, either collectively or individually, abilities superior to those of the eminent men who have preceded them in the same path; but they wish to apply, and apply effectively, all they do possess, and hope to be aided by the experience of others conversant with such subjects. They desire, if possible, to establish, by patient, direct and careful experiments, conducted on a scale sufliciently large, the immutable principles which ought to govern our calculations on the point of inquiry; and, lastly, they wish that the honour of effecting it may belong to the Institute 
winder whose auspices it originated, and the country of which they are proud to be citizens.

Your board are gratified to inform the Institute that the plan meets the approbation and encouragement of our city authorities, and that another public body has also evinced a disposition to aid and encourage them.

When the importance of the object to a very numerous class of our citizens, in the result of which they are directly or indirectly interested, is considered, the board feel assured that the means will not be withheld, and, as members of the Institute, you are respectfully requested to promote it by all the encouragement you may think it merits. All which is respectfully submitted.

$$
\text { William Hamilton, Actuary. }
$$

$$
\text { A. Mirler, Chairman, pro tem. }
$$

LIST OF ENGISSH PATENTS

Which passed the great seal, from September 25, to December 18, 1828.

To Peter Rigby Wason, Esq. Barrister at law, for his having invented a certain improvement in the article conmonly called stick sealing wax-September 25 .

To James Neville, Engineer, for his having invented an improved machine or apparatus, for obtaining mechanical power from falls and running streams of water-September $2 \tilde{5}$.

To Thomas Fowler, Stationer, for certain improvements in, or for raising and circulating hot water, hot oils, and other hot fluids for domestic and other purposes-October 2.

To Jobn Brunton, Engineer, for improvements in the apparatus for manufacturing coal gas and coke, and also improvements in the nethod of arranging such apparatus-October 2.

To David Napier, Engineer, for certain improvements in machinery applicable to letter press printing-October 2.

To Thomas Tippett, Engineer, for certain improvements in the construction and mode of working engines with steam and air, and in the boiler or generator of steam, and in the application of such improved engines to a new method of propelling of vessels and other floating bodies-October 9 .

To Samuel Lawson and Mark Walker, Machine makers and flax spinners, for having invented improvements in machinery for preparing and dressing hemp, flax, silk, and other fibrous substancesOctober 9.

To Henry Duxbury, Gentleman, for his having invented a new machine for splitting hides and skins-October 9 .

To Edward Hancorne, Nail manufacturer, in consequence of a communication made to him by a foreigner, residing abroad, for an invention for certain improvements in making nails-Octoher 16. 